\title{
Nano-approach towards Sustainable Agriculture and Precision Farming
}

\author{
Vedpriya Arya
}

Assistant Professor, Guru Nanak Girls College, Ludhiana, India

E.mail: ved.nano2008@gmail.com

Abstract-Nanotechnology is a most fascinating area of research now a days. The unique physicochemical properties of nanomaterials, that is, catalytic reactivity, high surface area, size and shape, have the potential to open new paradigms and to introduce new strategies in agriculture. Specific agronomic applications of nanotechnology include enabled delivery systems of release of agrochemicals allowing a controlled release of fertilizers, pesticides and herbicides, field-sensing systems to monitor the environmental stresses and crop conditions and improvement of plant traits against environmental stress and diseases. In the present review, a brief introduction about the recent nano-innovations in agriculture is introduced. This will paves the way to further investigations in this regard.

Keywords-Nanotechnology, Agriculture, Smart-Dust Technology.

\section{INTRODUCTION}

Man has learnt a lot from nature. Yet the manufacturing practices are primitive. Everyone knows that a lot more needs to be done to get closer to the nature. But definitely, Nature is a teacher of human for example, to create nanobots we go through the Bacterium flagellar motion, so that the nanobot can move inside the body fluids in a frequent manner. Pulse protein called Forisome can be utilized to create nanomotor. Nanosensors can be produced that have sensing power like ear, eyes and nose but not better than sensory organs of animals. Nanocomposites, nanomaterials etc. have emence functional applications.

\section{What is Nanotechnology?}

Nanotechnology is considered as an 'Umbrella' term as it blurs the boundaries between physics, chemistry and biology sciences (Dravid, 2004). It is a new area of science that involves working with materials and devices that are at the nanoscale level. A nanometer is a billionth of a meter that is about 1/80,000 of diameter of a human hair, or ten times the diameter of a hydrogen atom. It manipulates the chemical and physical properties of a substance at molecular level. Nanotechnology term was first coined by Norio Taniguchi in 1974. In 1980, Dr. K. Eric Drexier promoted technological significance of nanoscale phenomenon and devices (Pradeep, 2007).
Nanodimension is the range larger than an atom but smaller than a viral, bacterial or animal cell. The basic idea of nanoparticles formation is the Quantum confinement (Sastry, 2002). This means keeping the electrons trapped within a small area. Due to this, nanoparticles may have unusual physicochemical \& opto-electronic properties so discrete kind of functionality is expected. Nanoparticles are singly so important but in aggregated form they have tremendous functional applications that are recognized today. Nanoparticles aggregate to form some specific structures called Nanostructures. The widely used nanostructures are: Fullerenes, carbon nanotubes, dendrimers, quantum dots, nanoshells etc. The advanced nanotechnology involves the use of nanosensors, nanorobots, nanobodies, nanodevices etc. These materials have direct applications in each \& every field of science i.e. chemical, physical, biological, environmental or other sciences.

Nanotechnology has the potential to revolutionize the agricultural and food industry with novel tools for the molecular management of diseases, rapid disease detection, enhancing the ability of plants to absorb nutrients and others. On the other hand, nanobiotechnology can improve our understanding of the biology of various crops and thus can potentially enhance yields or nutritional values, as well as developing improved systems for monitoring environmental conditions and enhancing the ability of plants to absorb nutrients or pesticides. 


\section{SUSTAINABLE AGRICULTURE AND PRECISION FARMING: NEED AND IMPORTANCE}

The world agriculture is facing many challenges like changing climate, urbanization, sustainable use of natural resources and environmental issues like running off and accumulation of pesticides and fertilizers. These problems are further intensified by an alarming increase in food demand that will be needed to feed an estimated population of 6-9 billion by 2050. As fossil fuel resources are declining and industrial agriculture becomes increasingly inadequate, researchers are looking for new technologies to maintain high levels of food production (Siddiqui et.al, 2015).

\section{NANO-APPLICATIONS IN AGRICULTURE AND PRECISION FARMING}

Applications of nanotechnology in materials sciences and biomass conversion technologies applied in agriculture are the basis of providing food, feed, fiber, fire and fuels. In future, demand for the food will increase tremendously, while the natural resources such as land, water and soil fertility are limited. The cost of production inputs like chemical fertilizers and pesticides is expected to increase at an alarming rate due to limited reserves of fuel like natural gas and petroleum. In order to overcome these constraints, the precision farming is a better option to reduce production costs and to maximize the output, i.e., agricultural production (Siddiqui et.al, 2015).

\subsection{Smart field systems}

This is another interesting application of nanotechnology in the agricultural field. Smart field system also based on the use of the nanosensors by which a field is created that automatically detects, locates, reports and applies water, fertilizers and pesticides to the infected area. This methodology is currently working in the USA.

\subsection{Smart dust' technology}

This is an idea that thousands of tiny sensors could be scattered like invisible eyes, ears and noses across the farm fields and battle fields. Firstly, Kris Pister has developed autonomous nanosensors that are in the size of a match-stick head. Using silicon-etching technology, these 'motes' or (smart dust sensors) would feature onboard power supply, computational abilities and the ability to detect and then communicate with the other motes in the vicinity. In this way, the individual motes would self organize into computer networks and capable of relaying data using wireless technology.

The new radio telescope of the LOFAR (Low Frequency Array) project is based on tens of thousands of antennas that are connected to each other with a large ICT infrastructure. LOFAR Agro will make use of this infrastructure and has chosen as its first application the measurement of the micro-climate in potato crops. This information will be used to improve the advice on how to combat phytophthora within a crop, based on the circumstances within each individual field. So the system that provides the integration of smart system, sensing, localization, reporting and remote control can increase the efficiency and security (Scott and Chen, 2002). Nanotechnology in the fields operates at same scale as a virus or any other disease infecting particle infects the plant.

So, it holds the potential for very early detection and eradication like a bio-analytical nanosensors that could detect a single virus particle long before the virus multiplies and before the symptoms develop in the animals and in the plants (Drexier, 1986).

\subsection{Bioanalytical nanosensors}

These nanosensors are used to detect the pathogens, contaminants, environmental characters (light/dark, hot/cold, wet/dry) and particulates or allergens and heavy metals. These are small, portable, rapid response and processing speed, specific, quantitative, reliable, accurate, reproducible, robust and stable (Scott and Chen, 2002). One of the autonomous sensors for real time monitoring is the 'GPS system'. These nanosensors could be distributed throughout the field, where they can monitor the soil conditions, crop growth etc. These are widely used in the certain parts of USA and Australia. In agriculture and food systems, the new tools for the separation, identification and quantification of the individual molecules are developed.

However, this area needs various research to be explored such as nanobioreactor development is needed for the study of enzymatic processes, microbial kinetics, molecular ecology, mixed enzymes system and rapid assessment of response to the environmental factors (Scott and Chen, 2002). 


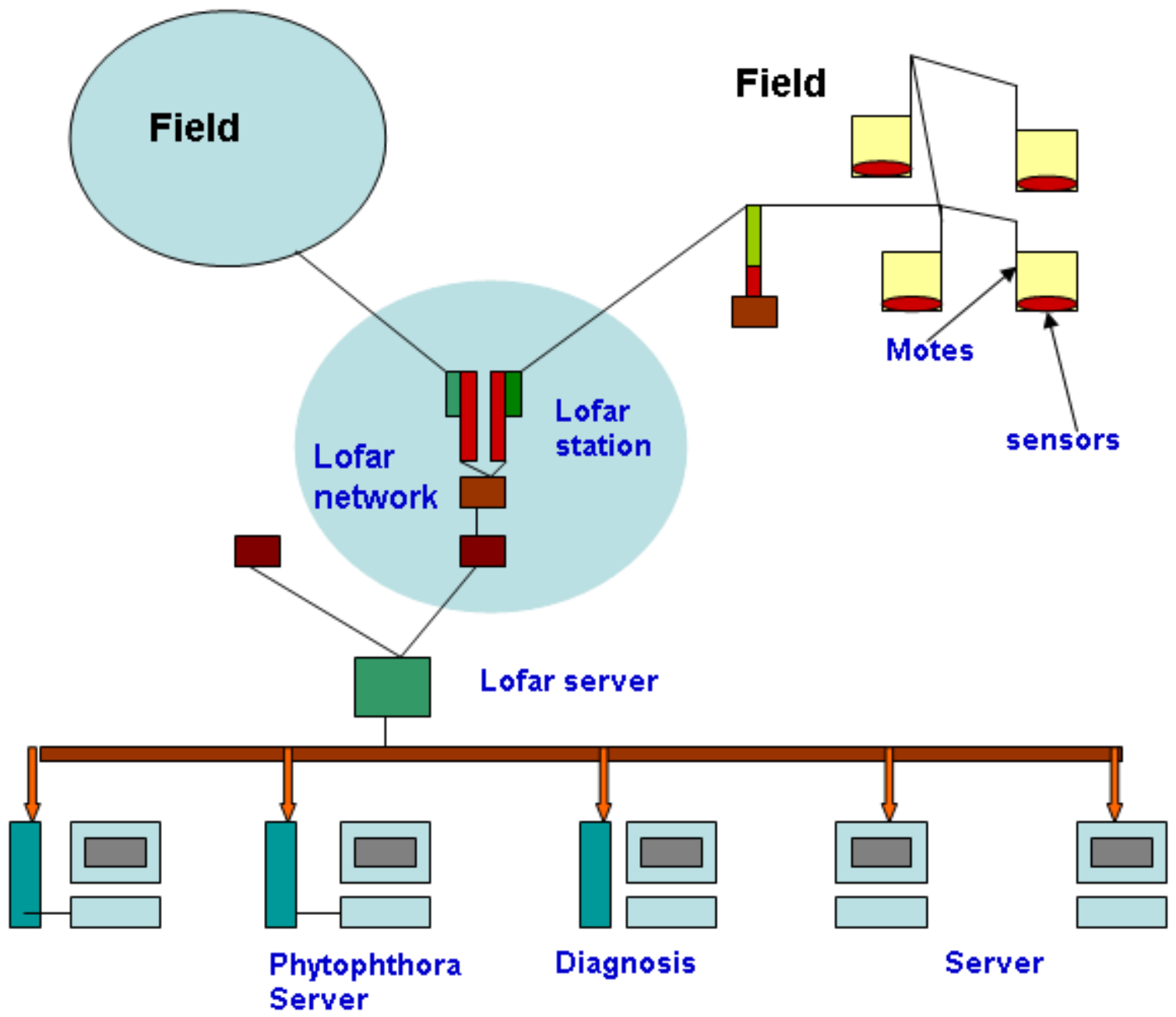

Network showing the smart dust technology in the field to detect the Phytophora

\begin{tabular}{|l|l|l|}
\hline Nanotechnologies & Examples & Potential applications \\
\hline $\begin{array}{l}\text { Energy storage, production } \\
\text { and conversion }\end{array}$ & $\begin{array}{l}\text { Novel hydrogen storage based on carbon nanotubes, } \\
\text { photovoltaic cells and organic light emitting devices } \\
\text { based on quantum dots. }\end{array}$ & $\begin{array}{l}\text { This provides cheaper, clean, low cost } \\
\text { solar cells and improved rechargeable } \\
\text { batteries. }\end{array}$ \\
\hline $\begin{array}{l}\text { Agricultural productivity } \\
\text { and enhancement }\end{array}$ & $\begin{array}{l}\text { Nanoporous Zeolites for slow release and efficient } \\
\text { delivery of the water and fertilizers for plants, } \\
\text { nanocapsules for herbicide delivery, nanosensors for } \\
\text { soil quality and plant health monitoring. }\end{array}$ & $\begin{array}{l}\text { These provide more efficient and } \\
\text { sustainable food production that requires } \\
\text { fewer inputs. }\end{array}$ \\
\hline Food processing and storage & $\begin{array}{l}\text { Nanocomposites used in plastic films for food } \\
\text { packaging, antimicrobial nanoemulsion for } \\
\text { decontamination of the food, nanotech based Ag } \\
\text { detection of the contaminants. }\end{array}$ & $\begin{array}{l}\text { Provide cheaper and safer food products } \\
\text { with stronger life. }\end{array}$ \\
\hline $\begin{array}{l}\text { Vector and pest detection } \\
\text { and control }\end{array}$ & Nanosensors for pests detection and control. & $\begin{array}{l}\text { More rapid and safer control strategies } \\
\text { with reduced loss. }\end{array}$ \\
\hline
\end{tabular}


3.4. Plants diseases Management

Tracing the path of plant pathogen - a new revolution in plant disease management

Fungus on the artificial leaf surface

Researchers are using the nanolithography (Fabrication technique) to fabricate the topographical surfaces that mimic leaf surface on which a particular pathogen can grow. They also trace the path and mechanism by which the pathogen invade and colonize inside the leaf. They use the imaging techniques like SEM (Scanning electron microscopy) and show how bacteria and fungi feel their way around the plant world. Hoch and his colleagues studied three diseases and trace the path of their causal organisms by the help of 'Nanolithography'. These diseases are 'Rust of beans', 'Anthracnose in corn' and 'Pierce disease of grapes'.

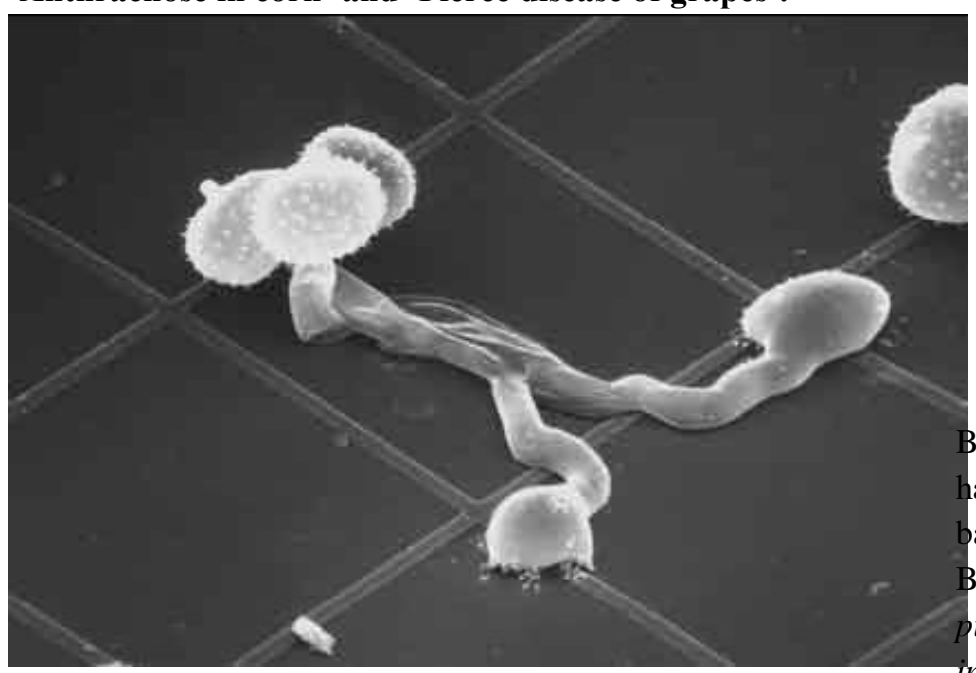

Rust disease in beans is caused by the Uromyces appendiculatus. Hoch and his team simulated the leaf topography by micro fabricating ridges on the silicon wafers using electron beam lithography (Mccandless, 2005). Then images of growing fungus are taken by the SEM. These images showed that the fungus crawls across the ridges until it senses a correct topographical feature that actually mimicking the 'stomata'. When this fungus finds the artificially made stomata like pores on the artificial leaf surface, then it develops the primary infection structure called 'Appressorium' and invade in the leaf tissue. The images and their further analysis show that ridges are $0.5 \mu \mathrm{m}$ high and this dimension is sufficient for the production of infectious appressorium. This information may be utilized in future to develop the plants with the stomatal aperture lower than $0.5 \mu \mathrm{m}$. This can be done by manipulating the genes in the plant genome responsible for the stomatal aperture size. These changes can make the more rust resistant plants.
Infact, research work on this thought has already been started by Burr and his colleagues in the management of the pierce disease of grapes that is caused by the bacteria Xyllela fasidiosa that moves upwards against the flow of sap in the plant xylem vessels and blocks them. The reasearchers have fabricated the micro fluidic chambers to mimic the plant xylem vessels. They have created the artificial xylem vessels using a silicon elastomer that was replicates from silicon wafers on to which the 'master' pattern were constructed with phytolithography.

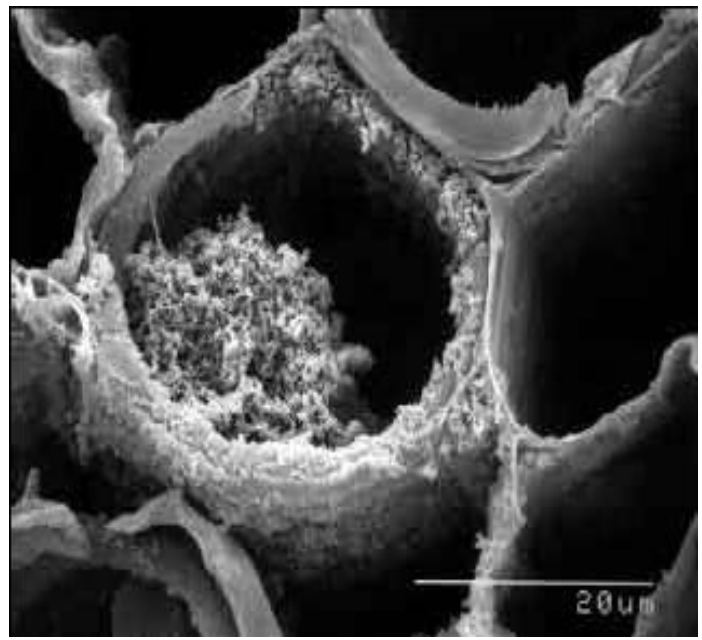

By SEM imaging, it was found that the bacteria have tiny air like structures called 'pilli' that was responsible for acteria attachment to the xylem walls. By this information, Burr and his workers interrupts the genes responsible for the illi formation and thus this mutant bacteria is now unable to infect and block the xylem vessels (Mccandless, 2005).

3.5. Nanoparticles involved Gene therapy for plants Nanoparticles involved Gene therapy for plants improving plant genetic characters

Nanoparticles are used for incorporating foreign DNA into the cells. For this purpose, carbon nanofibres are prepared from a silicon chip and artificially synthesized DNA strands attached to the nanofibres (McKnight, 2003). These loaded carbon nanofibres are then injected inside the plant cell and expresses inside the cell to synthesize a new protein and a new desired trait. This artificial DNA will remains attached to the carbon nanofibres and thus not transferred to the next generation. This technique enables the researchers to selectively switch on and off a key trait such as fertility. Moreover, mesoporous silica nanoparticles are used to transfer the foreign DNA inside the plant cell that uses a biolistic gun approach (Torney et. al, 2007). Not only DNA, but also RNA, small peptides and other materials can be 
successfully injected inside the plant cell, through this approach. With the mesoporous nanoparticles, we can deliver two biogenic species at the same time.

A gene can be induce in a controlled manner at the same time and at the same location. The biologists successfully used this technology to introduce DNA and chemicals to Arabidopsis, tobacco and corn plants.

These findings reveal the bright future aspects in the improvement of crop science. So by changes any unwanted gene and incorporating a desired gene through the nanoparticles, we can improve or install our desired character in the plant cell.

3.6. Atomically modified seeds

Seed characters can be improved by nanobiotechnology and the changed seeds are called as 'Atomically modified seeds'. These modified seeds are produced by drilling a hole through the membrane of rice cell and insert a nitrogen atom inside the cell. This foreign $\mathrm{N}$ atom stimulates the rearrangement of the rice DNA. By using this technique, rice variety colour is changed from purple to green. So this will help in changing the unwanted characters of the plants.

\subsection{Nanocides : pesticides via. Encapsulation}

Nanocides: pesticides via. encapsulation

The pesticides containing nano-scale active ingredients used for crop protection and disease management are called nanocides. Nanoparticles of about 10-150 nm size are used as an active ingredients in the pesticides. The advantage of using these nanoformulations is that the pesticides dissolve more readily in the water and can be simply applied over the crops. These are more stable and have high killing capacity.

\section{Nanocapsular formulation of the pesticides}

Formulation of the nanoscale pesticides involves encapsulation or packaging of the nanoscale active ingredients within a kind of tiny envelope or shell. This type of formulation reduces the contact of the active ingredients with agricultural workers and may have environmental advantages such as reducing run-off rates.

\section{Different nanocides available in the market}

\begin{tabular}{|l|l|l|}
\hline Companies & Nanocidal product & Characters of the product \\
\hline $\begin{array}{l}\text { BASF, Germany (world largest } \\
\text { chemical company) }\end{array}$ & $\begin{array}{l}\text { Nanoparticles as an active } \\
\text { ingredients in pesticides }\end{array}$ & $\begin{array}{l}\text { Nanocide can be easily dissolved in the } \\
\text { water and controls pests and herbs. }\end{array}$ \\
\hline $\begin{array}{l}\text { Bayers Crop Science, Germany } \\
\text { (world second largest pesticide firm) }\end{array}$ & Microemulsion concentrates & $\begin{array}{l}\text { More rapid, reliable and longterm } \\
\text { activity against pests. }\end{array}$ \\
\hline $\begin{array}{l}\text { Sygenta (world largest agrochemical } \\
\text { corporation) }\end{array}$ & $\begin{array}{l}\text { Primo MAXX plant growth } \\
\text { regulator }\end{array}$ & $\begin{array}{l}\text { These are oil based pesticides mixed with } \\
\text { water and then heated to create an } \\
\text { emulsion. }\end{array}$ \\
\hline
\end{tabular}

It consists of about 50 trillion capsules that are designed to be 'quick release' and breaks open in contact with the leaf of the plant. These capsules strongly adhere to the leaf so cannot be easily washed by the rain. The outer shell of these capsules opened only under special conditions example - 'Gutbuster' microcapsules breaks open in an alkaline environment such as stomach of certain insects. There are several benefits of using such nanocapsules like these nanocapsules have long lasting biological activity, less soil binding for better control of the pests, reduce workers exposure, reduce damage to the crops, less effect on other species, less pesticides loss by evaporation, prevents degradation of the active ingredients by sunlight etc.

\subsection{Photocatalysis using nanoparticles}

Photocatalysis is a reaction in which chemical compounds react in the presence of the light and itself is not being completely consumed in the reaction. In the presence of the UV light, the valance electrons in the nanoparticles are excited to form electron hole pairs. These negatively charged electrons and positive holes are the strong oxidizers. When harmful substances like pesticides stick to the positively charged holes, they are disintegrated into the harmless compound. The excited electrons are also injected in bacteria in contact of the nanoparticles and hence act as disinfectant and find application in fruit packaging and food engineering (Blake, 1997). Metal oxides uch as $\mathrm{TiO}_{2}$ (Bhatkhande et. al, 2001), $\mathrm{ZnO}$ ( $\mathrm{Li}$ and Haneda, 2003), $\mathrm{SnO}_{2}$ (Cao et. al, 2002) etc. as well as sulphides such as $\mathrm{ZnS}$ (Torres-Martinez et. al, 1999) have been used for photocatalysis. These nanoparticles 
have efficient disinfectant rates and are used to degrade the harmful pesticides that take long time in the decomposition.

\subsection{Nanobarcode Technology}

Nanobarcodes (Nice-Warner et. al, 2001) particles are encodeable, machine readable, durable, sub-micron sized taggants. They are free standing, cylindrically shaped metal nanoparticles having dimensions of $20-500 \mathrm{~nm}$ in diameter and $0.04-15 \mathrm{~nm}$ in length. The particles are manufactured in a semiautomated process by electroplating the inert metals (gold, silver) into templates defining particle diameter and then releasing the resulting striped nano-rods from the templates. These nanobarcodes are especially used for robust, uniquely identifiable nanoscale tagging of small items for authentication or tracking in the agricultural food and husbandary products.

\section{CONCLUSION AND FUTURE PROSPECTS (2)}

\section{Nanobiotechnology advances in Agriculture and Food}

\section{Development}

Nanobiotechnology, as a new versatile branch of nanotechnology, has the potential to revolutionize the agricultural science by providing new tools for agricultural development. Molecular treatment of the disease, rapid disease detection, enhancing ability of plants to absorbs nutrients, smart sensors, and smart delivery system will help the agricultural industry to combat viruses and other crop pathogens. Not only these, but there are several fields of agriculture where nanotechnology has shown its impact. Some of them are -

1. Precision farming 2. Smart dust technology 3. Nanotechnology in cell and molecular biology aspects of plants 4. Smart treatment delivery system 5. Agricultural waste treatment

However, these are so much expensive methods and are not currently being used in the developing countries. But most probably in near future, there are chances of the successful implementation of nanoscale devices in agriculture.

1. Precision farming - This is also called as 'site specific management'. It defines the unification of the information technology with the biology. Precision farming means growing crops in hundred percent efficient manner. Precision farming has a goal to maximize output (crop yield) and minimizing input (fertilizers, pesticides and herbicides etc.) through monitoring environmental variables and applying targeted action (Hummel et. al, 2000). This technique make use of the computers, global satellite positioning systems and remote sensing devices to measure highly localized environmental conditions thus determining whether crops are growing at maximum efficiency or precisely identifying the nature and location of problematic area. This information helps the farmer to keep the crops safe from infection (Birrell and Hummel, 1997).

The remote sensing nanodevice that is used here is the 'Nanosensors'. An interesting futuristic example of precision farming is given that a farmer while doing his household work gets information on his computer that a fungus is growing in north region of his field and penetrates about 0.2 feet in the soil. The farmer then goes to that particular region and applies suitable fungicides in that region only, so that disease gets cured before the macro symptoms would appear. This seems to be a dream but is going to be true by nanobiotechnology. Moreover, in USA this methodology is working currently.

\section{Benefits of precision farming -}

a. Precision farming promises higher yields and lower input costs by streamlining agricultural management and thereby reducing the waste and labour costs.

b. It also offers the potential to employ less skilled and cheaper farm machinery operators. Such systems can simplify and centralize decision making (Joseph and Morrison, 2006).

c. By pre-sensing the pathogens and infections, it is possible to eliminate the pathogens before the macro symptoms have appeared.

d. In the future, precision farming will resemble robotic farming as farm machinery is designed to operate autonomously, continuously adapting to incoming data.

Role of networks or wireless sensors in precision farming Wireless sensors are scattered on the fields and are interconnected via. a computer network system. These networked sensors are expected to provide detailed data on the crop and soil conditions. This system gives information in real time to remote location of abnormal reaction going on the field. Since many of the conditions that a farmer may want to monitor (for example- the presence of plant viruses, level of the soil nutrients, drought conditions etc.) for his safety of the crop can be easily predicted by operating this devices at the nanoscale. 
Bioanalytical nanosensors

Applications of nanotechnology in the agricultural field (Persad et. al, 2005)

\begin{tabular}{|l|l|l|}
\hline Nanotechnologies & Examples & Potential applications \\
\hline $\begin{array}{l}\text { Energy storage, production and } \\
\text { conversion }\end{array}$ & $\begin{array}{l}\text { Novel hydrogen storage based on carbon } \\
\text { nanotubes, photovoltaic cells and organic light } \\
\text { emitting devices based on quantum dots. }\end{array}$ & $\begin{array}{l}\text { This provides cheaper, clean, } \\
\text { low cost solar cells and } \\
\text { improved rechargeable } \\
\text { batteries. }\end{array}$ \\
\hline $\begin{array}{l}\text { Agricultural productivity and } \\
\text { enhancement }\end{array}$ & $\begin{array}{l}\text { Nanoporous Zeolites for slow release and } \\
\text { efficient delivery of the water and fertilizers for } \\
\text { plants, nanocapsules for herbicide delivery, } \\
\text { nanosensors for soil quality and plant health } \\
\text { monitoring. }\end{array}$ & $\begin{array}{l}\text { These provide more efficient } \\
\text { and sustainable food } \\
\text { production that requires fewer } \\
\text { inputs. }\end{array}$ \\
\hline Food processing and storage & $\begin{array}{l}\text { Nanocomposites used in plastic films for food } \\
\text { packaging, antimicrobial nanoemulsion for } \\
\text { decontamination of the food, nanotech based } \\
\text { Ag detection of the contaminants. }\end{array}$ & $\begin{array}{l}\text { Provide cheaper and safer } \\
\text { food products with stronger } \\
\text { life. }\end{array}$ \\
\hline $\begin{array}{l}\text { Vector and pest detection and } \\
\text { control }\end{array}$ & Nanosensors for pests detection and control. & $\begin{array}{l}\text { More rapid and safer control } \\
\text { strategies with reduced loss. }\end{array}$ \\
\hline
\end{tabular}

Tracing the path of plant pathogen - a new revolution in plant disease management

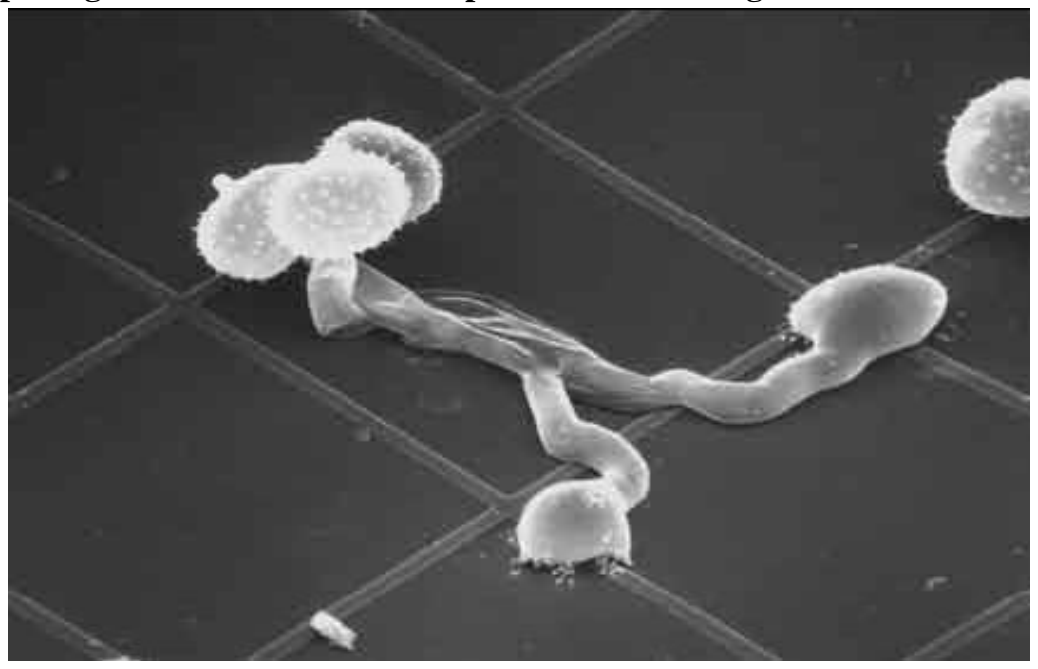

\section{Fungus on the artificial leaf surface}

Researchers are using the nanolithography (Fabrication technique) to fabricate the topographical surfaces that mimic leaf surface on which a particular pathogen can grow. They also trace the path and mechanism by which the pathogen invade and colonize inside the leaf. They use the imaging techniques like SEM (Scanning electron microscopy) and show how bacteria and fungi feel their way around the plant world. Hoch and his colleagues studied three diseases and trace the path of their causal organisms by the help of 'Nanolithography'. These diseases are 'Rust of beans', 'Anthracnose in corn' and 'Pierce disease of grapes'.
Rust disease in beans is caused by the Uromyces appendiculatus. Hoch and his team simulated the leaf topography by micro fabricating ridges on the silicon wafers using electron beam lithography (Mccandless, 2005). Then images of growing fungus are taken by the SEM. These images showed that the fungus crawls across the ridges until it senses a correct topographical feature that actually mimicking the 'stomata'. When this fungus finds the artificially made stomata like pores on the artificial leaf surface, then it develops the primary infection structure called 'Appressorium' and invade in the leaf tissue. The images and their further analysis show that ridges are $0.5 \mu \mathrm{m}$ 
high and this dimension is sufficient for the production of infectious appressorium. This information may be utilized in future to develop the plants with the stomatal aperture lower than $0.5 \mu \mathrm{m}$. This can be done by manipulating the genes in the plant genome responsible for the stomatal aperture size. These changes can make the more rust resistant plants. Infact, research work on this thought has already been started by Burr and his colleagues in the management of the pierce disease of grapes that is caused by the bacteria Xyllela fasidiosa that moves upwards against the flow of sap in the plant xylem vessels and blocks them. The reasearchers have fabricated the micro fluidic chambers to mimic the plant xylem vessels. They have created the artificial xylem vessels using a silicon elastomer that was replicates from silicon wafers on to which the 'master' pattern were constructed with phytolithography.

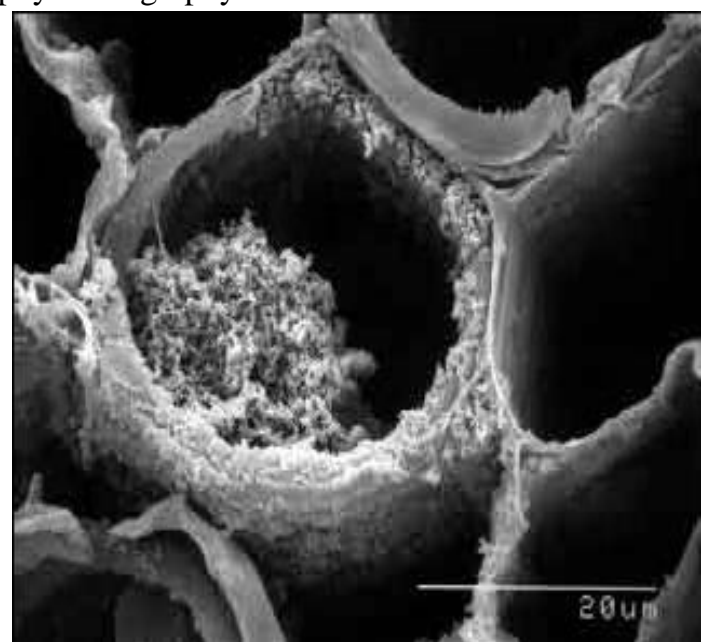

\begin{tabular}{|c|c|c|c|c|}
\hline Disease & Pathogen & Mode of entry & Nanofabrication & Management \\
\hline Rust of beans & $\begin{array}{l}\text { Uromyces } \\
\text { appendicuata }\end{array}$ & Through stomata & $\begin{array}{l}\text { Artificial leaf surface } \\
\text { through } \\
\text { nanolithography }\end{array}$ & $\begin{array}{l}\text { By developing plants } \\
\text { that have stomata size } \\
\text { less than } 0.5 \mu \mathrm{m}\end{array}$ \\
\hline Anthracnose in corn & $\begin{array}{l}\text { Colletotrichum } \\
\text { graminicola }\end{array}$ & $\begin{array}{l}\text { Through leaf surface } \\
\text { (any where) }\end{array}$ & $\begin{array}{l}\text { Nanofabrication of } \\
\text { the pillared surface on } \\
\text { silicon wafers }\end{array}$ & $\begin{array}{l}\text { By developing plants } \\
\text { that are less sensitive } \\
\text { to fungal infections }\end{array}$ \\
\hline $\begin{array}{lll}\text { Pierce disease of } & \text { of } \\
\text { grapes } & & \end{array}$ & Xyllela fasidiosa & $\begin{array}{l}\text { Through } \\
\text { vessels }\end{array}$ & $\begin{array}{lr}\text { Artificial } & \text { xylem } \\
\text { vessels } & \text { by } \\
\text { photolithography } & \end{array}$ & $\begin{array}{l}\text { By interrupting the } \\
\text { gene for pilli } \\
\text { formation in the } \\
\text { bacteria }\end{array}$ \\
\hline
\end{tabular}

By SEM imaging, it was found that the bacteria have tiny hair like structures called 'pilli' that was responsible for bacteria attachment to the xylem walls. By this information, Burr and his workers interrupts the genes responsible for the pilli formation and thus this mutant bacteria is now unable to infect and block the xylem vessels (Mccandless, 2005).

\section{Blocked xylem vessels}

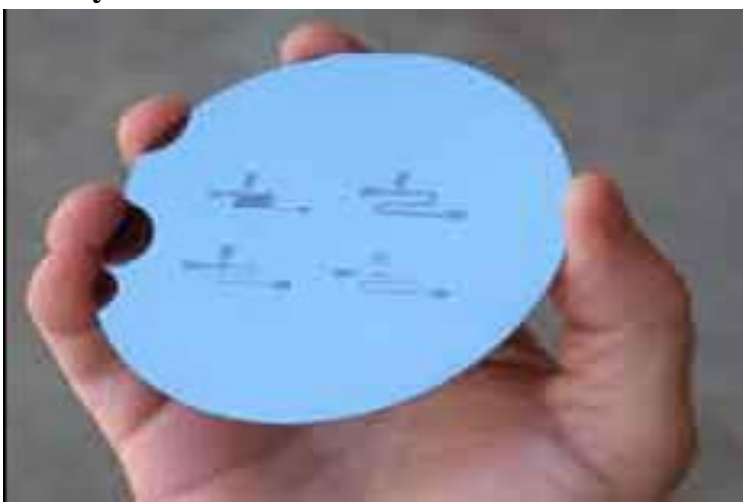

Master patterns used to produce artificial xylem vessels This is the wonderful approach that can be used in management of several disease in the plants. Plant pathogens due to extremely small size can not be traced with any other technique, only this nanolithography enables the researchers to closely monitor the secret path of pathogen for infecting the plants.

Nanolithographical manipulations results in disease management 


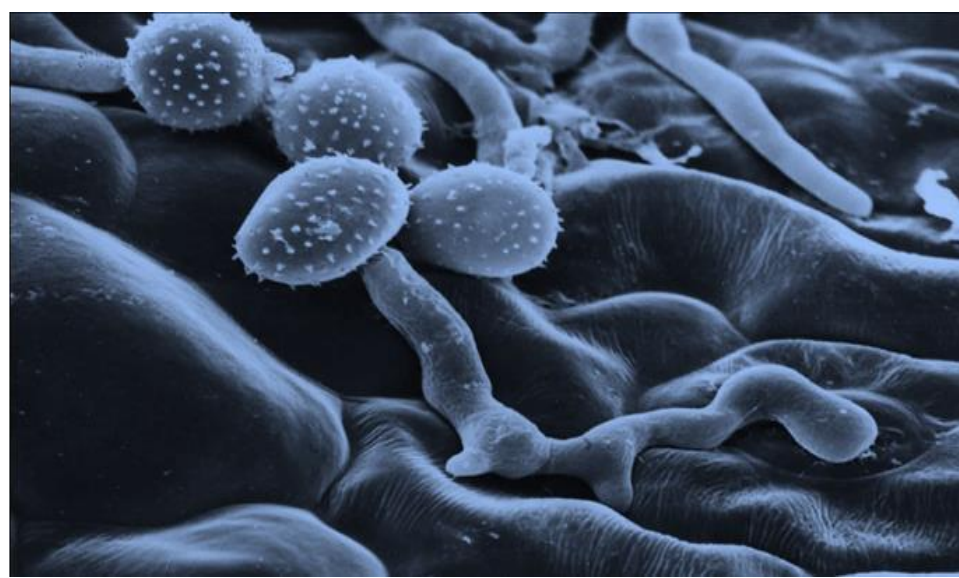

Rust fungus growing on the artificial leaf surface

\section{REFERENCES}

[1] Dravid, V. P. 2004. Integrating emerging Bio nanostructures on emerging plateform - Bottom up meets top-down. Inst. for nanotech. North - western Univ. Evanston, USA

[2] Pradeep, T. 2007. Diversity in nanosystems. In: Pradeep, T (eds), Nano:The essentials - Understanding Nanoscience and Nanotechnology. pp 89-122, Tata McGraw Hill, New delhi

[3] Sastry, M. 2002. Assembling nanoparticles and biomacromolecules using electrostatic interactions. Pure Appl. Chem. 74(9):1621-1630

[4] Siddiqui, M. H., Al-Whaibi, M. H., \& Mohammad, F.

(2015). Nanotechnology and Plant Sciences: Nanoparticles and Their Impact on Plants. 